\title{
SVETI GRGUR VELIKI U NJEMAČKO-RIMSKOM BREVIJARU (1518.), NA FRESKAMA U SVETICAMA (1541.) I U RAJU DUŠE (1560.) KOJE SU NARUČILI FRANKAPANI MODRUŠKI I OZALJSKI*
}

Grof je Krsto (Kristofor) Frankapan Modruški i Ozaljski sa suprugom Apolonijom Lang od Wellenburga za trajanja uzništva u Veneciji (1514. - 1519.) pripremio i dao tiskati Njemačkorimski brevijar u kojem je svoje mjesto našao i sveti Grgur Veliki. Kao i stric joj Krsto, Katarina Frankapan je dala 1560. otisnuti časoslov Hortvlvs Animae [Stoye Rechi Ray Dusse] u kojem su posljednje dvije molitve na hrvatskom jeziku - molitve Grgura Velikog. Ustrajno inzistiranje na promidžbi toga crkvenog oca, »najvećeg među svim papama«, »rodom« Frankapana, predstavlja ne samo nov iskorak u razvoju predodžbe (gotovo pa utemeljene na ikonografskom argumentu konvenijencije) Frankapana Modruških i Ozaljskih, već odgovara i na pitanja percepcije moći članova te obitelji, kao i njihove simboličke komunikacije unutar europskih političkih/dvorskih i crkvenih krugova.

Ključne riječi: Grgur Veliki, Frankapani Modruški i Ozaljski, Njemačko-rimski brevijar, freske u Sveticama, časoslov Raj duše, simbolička komunikacija, (samo)promocija, 16. stoljeće

\section{1. »GREGORIVS I DE FRANGIPANIBVS «}

Predaja o tome da papa sv. Grgur Veliki (590. - 604.) potječe iz roda Frankapana bila je tijekom kasnoga srednjeg i ranoga novog vijeka općeprihvaćenom i neupitnom na prostorima zapadnog kršćanstva, što je Frankapanima Modruškim i Ozaljskim bilo jednim od vrlo važnih elemenata (samo)predstavljanja u visokim europskim političkim i crkvenim krugovima

* Tekst je pripremljen u okviru projekta »Izvori, pomagala i studije za hrvatsku povijest od srednjeg vijeka do kraja dugog 19. stoljeća « Hrvatske zaklade za znanost (šifra: 6547), kojemu je voditelj znanstveni savjetnik dr. sc. Damir Karbić. 
u kojima su se kretali. U 17. je stoljeću, primjerice, otisnuta knjiga o Frankapanima u kojoj se sasvim benevolentno prihvaćaju tvrdnje crkvenih autoriteta poput papa Martina V. (1417. - 1431.) i Pija II. (1458. - 1464.) da su knezovi Krčki potekli od Frankapana kojima su najuglednijim članovima bili pape Feliks III. (483. - 492.) i njegov praunuk sv. Grgur Veliki. ${ }^{1}$

Podrijetlo, dakle, iz obitelji, koja je dala crkvenog oca (sv. Grgura) te pripadnost zemlji iz koje je drugi crkveni otac rođenjem potekao i kojoj je kako se vjerovalo podario glagoljicu (sv. Jeronim) - bili su iznimno važnim temeljima na kojima su Frankapani Modruški i Ozaljski krajem 15. i tijekom 16. st. gradili identitet svoje obitelji, a što se evo ogleda i u vizualnim izvorima koje su sami producirali ili su ih reciklirali uglednici koji su s tom tradicijom bili upoznati. ${ }^{2}$ No, kako je takva baština na frankapanskim prostorima od Ozlja do Vinodola i Senja preživjela u tragovima, ${ }^{3}$ potrebno ju je analizirati i potom induktivnim pristupom zaključiti jesu li Frankapani zaista kreirali obiteljski identitet na takav način. Slijedom takva pristupa će u ovom tekstu biti predstavljeni Krstin i Apolonijin brevijar (1518.) i časoslov Krstine nećakinje Katarine (1560.), a kao konvergencijski argumenti (u smislu abdukcijske potvrde) u korist navedene hipoteze će poslužiti i nedavno otkrivene freske u crkvi Rođenja Blažene Djevice Marije u Sveticama kraj Ozlja nastale oko 1541. godine.

\section{2. »TOLIKO JE TREBALO REĆI O KRSTINU BREVIJARU«}

O petstotoj obljetnici Njemačko-rimskog brevijara, koji su Krsto Frankapan i supruga mu Apolonija Lang od Wellenburga za trajanja njegova uzniš-

1 Usp. ZAZZERA D'ARAGONIA 1617, poglavlje: »Della famiglia Frangipani d'Vngheria di Dalmazia e del Frivle« poput ovakvih navoda: Frangipanibus, de qua fuit Papa Gregorius magnus Eccl. doctor ...; Faelix 3. natione Italus ... de nobilissima domo Anicia, quae postea Frangipanum appellata est.; Hi fuerunt Epiiscopi duo, Cenadiensis, \& Segniensis; \& cum his Stephanus Croatiae Comes ab origine Romanus Frangepania gente, quam sanctissimum olim Pont. Gregorium produxit...

2 O pozadini nastanka i širenja predaje/mita o frankapanskom podrijetlu knezova Krčkih vidi: ŠPOLJARIĆ 2016 i u tom članku navedene izvore i literaturu. O širenju predaje/mita o sv. Jeronimu kao tvorcu glagoljice vidi: HERCIGONJA 2004: 11-56, cijelo poglavlje »Hrvatska glagoljica u zapadnoeuropskoj (francuskoj i talijanskoj) znanstvenoj literaturi i enciklopedistici od XVI. do XVIII. stoljeća

3 Pomična baština koja je navezana na sv. Grgura Velikog (rukopisi, knjige, sitniji crkveni namještaj poput relikvijara i manjih oltara i sl.) danas u pravilu nije pohranjena u mjestima nastanka. Tako se, primjerice, u Hrvatskoj akademiji znanosti i umjetnosti čuvaju četiri glagoljska rukopisa Dijalog Grgura pape koja su do 17. st. nastala na frankapanskim prostorima; usp. ŠTEFANIĆ 1969: 189-192. Isto tako je kip sv. Grgura Velikog, uz kip sv. Pavla Pustinjaka prenesen iz senjske pavlinske crkve u Punat na otoku Krku; TULIĆ 2012: 174, kat. br. 16. Takva dislocirana djela otežavaju znanstveno istraživanje. 
tva u Mlecima (1514. - 1519.) pripremili u suradnji s njemačkim franjevcem Jakovom (Jacob) Wygom i dali otisnuti, ${ }^{4}$ valja pripomenuti kako se o njemu piše već stoljećima, ali ga svejedno uz određene poteškoće »pronalazi« svaki sljedeći naraštaj znanstvenika. Brevijar se, naime, u ranijim priručnicima često registrirao kao Petbuch die Syben Zeit van Latein in Deutsch gemacht pa je pod tim naslovom naveden čak i u Hrvatskom biografskom leksikonu. ${ }^{5} \mathrm{U}$ hrvatskoj znanstvenoj literaturi je Matija Mesić u suradnji s Ivanom Kostrenčićem prvi upozorio na postojanje Krstina brevijara (MESIĆ 1870: 77-79), ali je širokoj čitalačkoj publici postao poznat tek nakon 1895. kada je izišao povijesni roman o Apoloniji i Krsti iz pera njemačkog povjesničara umjetnosti Henryja Thodea. ${ }^{6}$ Nakon tog su romana u više navrata i preko dnevnih tiskovina i preko znanstvenih radova pružani kraći ili nešto detaljniji opisi tog brevijara, ${ }^{7}$ ali se njime nitko u Hrvatskoj nije ozbiljnije pozabavio pa tako ni prisutnošću sv. Grgura Velikog u njemu do sada.

Brevijar je opremljen kalendarom s urešenim slikovnim alegorijama mjeseci kroz godinu, grbovima obitelji Frankapana i Langovih, potom nizom medaljona, četirima ornamentima i brojnim ukrašenim inicijalima te sitnim drvoreznim prikazima s različitim simboličkim figurama. No, među slikovnim prilozima najljepši su deset velikih slikovnih otisaka. ${ }^{8}$ Prvi i posljednji su identični, a sadrže prikaz motiva Krunjenje B. D. Marije podno kojeg Krsto i Apolonija sučelice klečeći

${ }^{4}$ FRANKAPAN; LANG; WYG 1518. Pored petnaest primjeraka tog brevijara koji su navedeni u bilj. 1. članka: JURKOVIĆ 2017.a, još se šest primjeraka čuva u: Australiji (Melbourne, State Library Victoria - Sticht Collection, sign. 347[2]), Italiji (Gardone Riviera, Biblioteca della Fondazione Il Vittoriale degli Italiani, sign. ZTN 10; Trento, Biblioteca Diocesana Vigilianum, sign. LO 125), Njemačkoj (Eichstätt - Ingolstadt, Katolische Universität, Universitätsbibliothek, sign. 04/1 AÖ 15) i Sjedinjenim Američkim Državama (Cambridge, Harvard Library, sign. Houghton Typ 525 18.262; Chicago, Newberry Library, sign. VALUT Wing ZP 535.G866). Brevijar se može izlistavati preko mrežnih stranica dviju knjižnica: Austrijske nacionalne knjižnice u Beču (http://digital.onb.ac.at/OnbViewer/viewer.faces?doc=ABO_ \%2BZ221484602) (23. 10. 2018.) i Bavarske državne knjižnice u Münchenu na koju me upozorila voditeljica Knjižnice Filozofskog fakulteta Sveučilišta Jurja Dobrile u Puli, Vanessa Toić, na čemu joj iskreno zahvaljujem. Vidi URL: http://reader.digitale-sammlungen. de/de/fs1/object/display/bsb10164199_00001.html (23. 10. 2018.)

5 Usp. primjerice: PANZERS 1788: 411-412; MOSEL 1835: 338; LJUBIĆ 1880: 61-62; STRĆIĆ 1998.

6 Thodeova knjiga o Frankapanima (THODE 1895) doživjela je i engleska izdanja (THODE 1900 i 1904) te na koncu i hrvatsko izdanje: THODE 1944 i 1992: 139-141.

7 Usp. LUCERNA 1925; ŽIC 1933; ŠERCER 2011: 57-60; KRUHEK 2016: 130-133; JURKOVIĆ 2017.b.

8 Na temelju inicijala koji se pojavljuju na nekoliko oslika Georg Kaspar Nagler ih je sve pripisao poznatomu mletačkom izdavaču, tiskaru i drvorescu Giovanniju A. Vavassoreu (NAGLER 1879: 412, br. 2053), premda su se kasniji znanstveni autoriteti ogradili o tu atribuciju; usp. SANDER 1941: lvii-lviii. 
mole sklopljenih ruku. ${ }^{9}$ Preostalih osam otisaka prikazuju najvažnije događaje Novog zavjeta, od Navještenja do Susreta na Zlatnim vratima. ${ }^{10}$ Ti su otisci sa sve četiri strane dodatno ukrašeni medaljonima koji se opetovano pojavljuju u raznim kombinacijama. U dva je takva medaljona svoje mjesto našao i prikaz Svetog Grgura Velikog kao jedan od četiriju crkvenih otaca Katoličke Crkve. ${ }^{11}$ Tijekom mletačkog uzništva, Krsto i Apolonija su vjerojatno birali i slikovnu opremu brevijara, što je na koncu rezultiralo čestim odabirom upravo onih medaljona u kojima je i lik Svetog Grgura Velikog, a na uštrb četvorice evanđelista, koji bi se morali ikonografski javljati paralelno s likovima crkvenih otaca. ${ }^{12}$

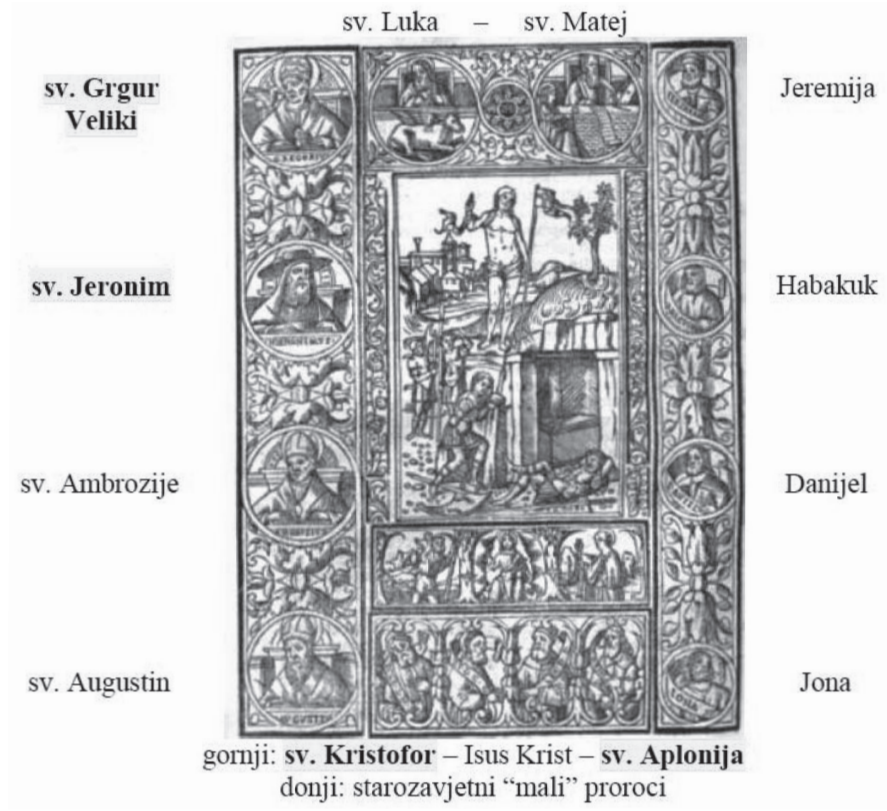

Slika 1. Uskrsnuće, u: FRANKAPAN; LANG; WYG 1518: f. 226v

Figure 1. Ressurection, in: FRANKAPAN; LANG; WYG 1518: f. 226v

\footnotetext{
${ }^{9}$ Prikaz je motiva Krunjenje B. D. Marije podno kojeg Krsto i Apolonija sučelice mole reproduciran u raznim prigodama, primjerice: THODE 1992: 148; KLAIĆ 1973: 295; PANTELIĆ 1981: 366, sl. 107; HORVAT 2006: 546; KRUHEK 2009: 212, sl. 7; ŠERCER 2011: 59; KRUHEK 2016: 132, sl. 38.

${ }^{10}$ V. FRANKAPAN; LANG; WYG 1518: Navještenje (f. 94v), Rođenje Kristovo (120v), Poklonstvo Trojice Krajeva (145v), Uskrsnuće (226v), Uzašašće (246v), Duhovi (253v), Sv. Petar okružen svecima i sveticama (435v) i Susret na Zlatnim vratima $(452 \mathrm{v})$.

${ }^{11}$ Grgur Veliki se u brevijaru učestalo spominje, a hagiografski prikaz njegova života nalazi se na: f. 332r-332v.

12 Usp. BADURINA 1979: 185.
} 
Ovom prilikom valja spomenuti i drugoga crkvenog oca, koji se još u vrijeme nastanka Njemačko-rimskog brevijara štovao u hrvatskim zemljama kao zaštitnik ilirskih zemalja i izumitelj glagoljice - sv. Jeronima. S obzirom na redoslijed $u$ medaljonu, vidljivo je sljedeće: Grgur je na prvom mjestu, ${ }^{13}$ Jeronim na drugom i tek potom slijede Ambrozije i Augustin. Od evanđelista su, primjerice, na gornjem medaljonu samo Luka i Matej. Starozavjetni su Veliki proroci u desnom, a Mali proroci u donjem medaljonu. Između donjeg medaljona i središnjeg oslika Uskrsnuće smješten je medaljon s prikazom Isusa Krista kojemu s desna prilazi sv. Kristofor, a s lijeva je lik sv. Apolonije (Slika 1).

Krsto je, dakle, imao potrebu na nenametljiv način vizualizirati vlastiti identitet vjerničkomu puku i u njemačkim zemljama. Kao što je korištenjem medaljona s prikazom Krista, sv. Kristofora i sv. Apolonije, naznačio da je s Apolonijom bio pokrovitelj i donator Njemačko-rimskog brevijara, tako je prikazima crkvenih otaca sv. Grgura Velikog i sv. Jeronima naznačio svoje obiteljsko (Grgur - Frankapan) i zavičajno (Jeronim - Dalmatinac) podrijetlo pa zaključujemo, poput Matije Mesića, da je ovom prilikom barem toliko »trebalo reći o Krstinu brevijaru« (MESIĆ 1870: 78).

\section{3. »MOLLITUA S. GARGURA«}

Donedavna se vjerovalo kako je u knjižnici franjevačkog samostana na Trsatu ${ }^{14}$ sačuvan jedini primjerak Katarinina molitvenika Raj duše,${ }^{15}$ koji je nekoć bio vlasništvom bratovštine Blažene Djevice Marije na Trsatu. ${ }^{16}$ Upra-

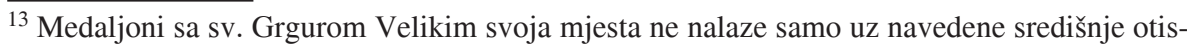
ke, već i na početnim stranicama pojedinih poglavlja brevijara kao njihov ukras - lijevo ili desno od njih; usp. primjerice FRANKAPAN; LANG; WYG 1518: ff. 1r, 94v, 120v, 146r, 226v, 246v, 247r, 300v, 452v i 601r.

${ }^{14}$ Primjerak tog časoslova nalazi se u Münchenu (Bayerische Staatsbibliothek, sign. Rar. 1889 - a dostupan je i u digitalnoj formi na mrežnoj stranici: http://reader.digitale-sammlungen. de/de/fs1/object/display/bsb10860380_00001.html (23. 10. 2018.) Pretisak molitvenika Raj duše (DEŠIĆ 1995) za izvornik ima primjerak koji se čuva u Franjevačkom samostanu na Trsatu.

${ }^{15}$ Prema Julijanskom kalendaru godina 1559. počinje u nedjelju (1. siječnja) baš kao i u Raju duše (usp. f. A2r-A8v). Rad se na molitveniku po svemu sudeći oduljio pa je možda i neplanirano otisnut u sljedećoj, 1560. godini. Za tvrdnje da je trsatski primjerak Raja duše unikatan v. HOŠKO 1981: 99; ŠUNDALIĆ 2003: 145; HOŠKO 2007: 61 i 65; RELJAC 2015: 136.

${ }^{16} \mathrm{Na}$ pozadini početne stranice trsatskog primjerka Raja duše pojavljuje se, (očigledno) naknadno nalijepljen prikaz Blažene Djevice Marije na način da kršćanski puk štiti svojim ogrtačem, tj. Gospa od Milosti (lat. Mater misericordiae) s uokvirenim tekstom na latinskom »B. Virg. Sodalitas« (tj. Beatae Virginae Sodalitas) smještenim na dnu te slike (usp. KUNČIĆ 2008: 135-148). Ta bi naljepnica mogla biti oznaka vlasnika knjige. Naime, u franjevačkom 
vo se s tog razloga priredio pretisak (DEŠIĆ 1560) s uvodnom studijom, zasebno tiskanom i uvezanom, a pripremili su je akademici Milan Moguš i Josip Vončina (MOGUŠ; VONČINA 1995). Prilikom opisa Raja duše stavili su naglasak, između ostalog, i na molitve sv. Augustinu jer su s pravom primijetili, citirajući ih, da je Katarina na tim mjestima otvoreno molila za zdravlje te su zaključili da je ona u to vrijeme bila »shrvana bolešću « i da »neće dugo poživjeti«. Sažeto su potom opis dovršili konstatacijom da na kraju molitvenika slijede »Katarinine molitve jedna za drugom s uvijek istim pridjevkom u odnosu prema Bogu - službenica tvoja ${ }^{17}{ }^{17}$

Molitvenik nema, doduše, slikovne priloge na kojima su Grgur Veliki ili sv. Katarina kao asocijacija na njegovu naručiteljicu. No, u kalendaru su na njegovu početku blagdani tih dvoje svetaca istaknuti crvenim podebljanim slovima. ${ }^{18}$ Osim toga, u njemu je jedna molitva upućena sv. Katarini ${ }^{19}$ i, što je iznimno važno, prije samog su njegova kraja otisnute čak dvije molitve sv. Grgura Velikog, dakle prije Sv. mise B. D. Marije na latinskom jeziku. ${ }^{20}$ U zaglavljima stranica na kojima se nalaze te dvije molitve, one su vrlo jednostavno istaknute crvenim slovima: »Mollitua S. Gargura ${ }^{21} R a j$ duše je, eto, završio molitvama sv. Grgura Velikog na hrvatskom jeziku, što jest očigledna namjera Katarine Frankapan i Nikole Dešića, priređivačâ molitvenika, da ga »smjeste« na prikladno i lako pamtljivo mjesto. Uostalom, zašto i ne bi? Ta nije li Katarina potekla iz iste obitelji kao i sv. Grgur? Ne dokazuju li to i njihovi »govoreći« grbovi - lavovi koji propeti na stražnjim nogama sučelice prednjim šapama lome kruh, ${ }^{22}$ a koji je Katarina otisnula

je samostanu na Trsatu vjerojatno djelovala muška bratovština posvećena B. D. Mariji jer su pod Marijinim plaštem sami bratimi (usp. ŠUNDALIĆ 2003: 122; HOŠKO 2007: 62). U primjerku Katarinina časoslova u Münchenu nema takvoga, već je ex libris Knjižnice izbornoga bavarskog kneza nalijepljen na unutarnjoj strani prednje korice časoslova.

${ }^{17}$ Usp. MOGUŠ; VONČINA 1995: 40-41. Katarina Frankapan nakon posljednjeg poroda (kćeri Magde) uskoro je i umrla (1561.): usp. VARGA 2016: 32.

${ }^{18}$ Usp. DEŠIĆ 1560: ff. A3 i A8. Znakovito je da je u tom kalendaru među blagdanima crkvenih otaca masnim crvenim slovima, uz spomenuti Grgura Velikog, istaknut i blagdan sv. Jeronima, a da to nije učinjeno za sv. Augustina i Ambrozija.

${ }^{19}$ Isto. f. 202v-203r: »Od suete Chaterine Antiph.«.

${ }^{20}$ Isto. f. 250r-251v: »Incipit Missa beatę Mariae virginis«. O Raju duše kao o marijanskom molitveniku, vidi: ŠUNDALIĆ 2003: 117-146; GAŠPAR; PAVLIĆ 2015.

${ }^{21}$ Prva je molitva podugačko naslovljena: »Tu mollituu choi vssachi dan ponizno mollil buded (chaco gouori sueti Gargur) Diaual ni nitchor od zallih liudi gniemu nemochichie naschoditi. I gda souoga suita premine Paccal nechie imat oblast priyet dussu niegouu « (isto. f. 246r-247v, naglašavanje I. J.), a druga: »Molitua Blaxenoga suetoga Gargura Pape od pet Raan Boxgih« (isto. f. 247v-249r, naglašavanje I. J.)

${ }^{22}$ Najljepši prikazi frankapanskih grbova se nalaze u tzv. Fuggerovim grbovnicima. Naime, za svoju je knjižnicu bogati augsburški plemić Johann Jakob Fugger (1516. - 1575.) naručio 
na »trećoj stranici«Raja duše u heraldički gornjem lijevom polju svojega kvadriranog grba?23

\section{GRGUR VELIKI U SVETICAMA}

Radovi koje su od 1992. s prekidima do 2005. god. u pavlinskoj crkvi Rođenja B. D. Marije u Sveticama (jugozapadno od Ozlja) vodili djelatnici Konzervatorskog odjela u Karlovcu pod vodstvom prof. Marinke Mužar iznjedrili su na vidjelo freske nastale oko 1541. god. među kojima i sv. Grgura Velikog ispod jednog od čak tri gotički oslikana frankapanska grba. Upravo su ti grbovi znanstvenicima zaokupili pažnju, ${ }^{24}$ a glede zidne slike sv. Grgura Velikog, on je tek ispravno atribuiran zahvaljujući čemu je freska i obnovljena. ${ }^{25}$ Time je poglavlje o sv. Grguru bilo lakonski zaključeno. ${ }^{26}$ Uostalom, konzervatorima i povjesničarima umjetnosti je primarnim zadatkom bilo utvrditi djelatnost radionice domaćeg majstora koji je freskama opremio i crkve u Zadobarju i Volavju, mjestima koja su se sa Sveticama nalazila na frankapanskom vlastelinstvu Ozalj, te pored njih i onima u susjednim mjestima Kranjske. ${ }^{27}$ Stilska obilježja tih zidnih slika upućuju na zakašnjele gotičke forme koje su u djelovanju te radionice sredine 16 . stoljeća lako prepoznatljive.

od prijatelja i suradnika - poznatog umjetnika, izumitelja i antikvara Jacopa Strade (1507. - 1588.), rodom iz Mantove - petnaest svezaka grbovnika talijanskih vladarskih i plemićkih obitelji te crkvenih dostojanstvenika. Ta reprezentativna zbirka nastala je između 1550 . i 1555. godine te je na koncu završila u knjižnici bavarskog vojvode Alberta V. Wittelsbacha Velikodušnog (1528. - 1579.), u čijoj je službi bio Fugger. Svi su svesci dostupni preko početne mrežne stranice projekta BSB-CodIcon online (http://codicon.digitale-sammlungen. de/start.html (23. 10. 2018)) tako da se pristupa preko poveznice Heraldik i potom s popisa digitaliziranih rukopisa izaberu od Cod.icon. 266 [Katalog] do Cod.icon. 280 [Katalog]. Zbirka započinje grbovima Frankapana (!), onih papa Feliksa III. i Grgura Velikog: pristup mrežnoj stranici kao što je prethodno navedeno na Cod.icon. 266 [Katalog] pod naslovom: Insignia pontificum Romanorum et cardinalium. I. Insignia a Felice III. ad Paulum IV., ff. $1 \mathrm{r}$ i 2 r (23. 10. 2018.). O uputama na grbove rimskih, napuljskih i venecijanskih Frankapana u toj zbirci vidi: JURKOVIĆ 2017.a.: 76-77, bilj. 46-48.

${ }^{23}$ Usp. JURKOVIĆ 2017.a.: 63-64 i 78-81.

${ }^{24}$ Usp. isto. 61-70. i u tom članku navedenu literaturu.

${ }^{25}$ Obnovu atribuiranih fresaka obavili su akademski slikari Damir Facan i Zlatan Kovač na temelju povijesno-umjetničkih analiza Marinke Mužar; usp. HORVAT 2010: 197, bilj. 4.

${ }^{26}$ Atribucija je objašnjena i kvalitetna crno-bijela slika (RATKOVČIĆ 2008: 201-202, sl. 9), a potom i slika u boji sv. Grgura Velikog objavljena je u: RATKOVČIĆ 2014: 213. Slike u boji su, doduše bez ikakva popratnog teksta ili objašnjenja, objavljene i u: JURINIĆ [2012]: 38. Slike tek glave i poprsja sv. Grgura u boji s namjerom isticanja frankapanskih grbova bez ikakva komentara o Grguru: KRUHEK 2016: 170-171, sl. 50-51.

${ }^{27}$ Usp. također: RATKOVČIĆ; MIKŠIĆ 2017: 33-34. te gornje ilustracije na str. 36-37. 
Sveti Grgur Veliki je, dakle, smješten u donjemu lijevom pojasu prozora na istočnom zidu crkve Rođenja B. D. Marije u Sveticama. Prikazan je kako sjedi na prijestolju s ikonografskim atributima koji ga identificiraju: sa štapom koji završava s križem u lijevoj ruci, tijarom na glavi i bijelom golubicom pokraj njegova desnog uha. ${ }^{28} \mathrm{U}$ pojasu ponad njega je kvadrirani grb Frankapana, koji smo objasnilii ${ }^{29}$ i koji u gornjem dijelu (kaciga, dio plašta, nakit, točenica, znak dostojanstva) nije sačuvan. U donjemu desnom pojasu prozora vidljiv je samo fragment crvenoga kardinalskog šešira, što je atribut sv. Jeronima, ${ }^{30}$ a nad njim je natpis »TRINITATIS«, nakon kojeg na vrhu slijedi zrcalno oslikan grb Frankapana na gotovo istovjetan način okljaštren kao i onaj ponad lika Svetog Grgura Velikog (Slika 2). ${ }^{31}$

Područja susjednog prozora u svetištu crkve, međutim, podijeljena su u tri pojasa. U srednjem su pojasu sa svake strane prozora po jedan zoomorfni simbol; lijevo sv. Ivana (orao) i desno sv. Marka (krilati lav) nad kojima su i likovi upravo te dvojice evanđelista kako sjede i pišu na klupi, dok su ispod zoomorfnih simbola dvojica crkvenih otaca, sv. Ambrozije (lijevo) i sv. Augustin (desno). ${ }^{32}$ Ti su dijelovi ciklusa zidnog oslika ispravno objašnjeni, atribuirani i obnovljeni. No, argumentacija (grbovi) s kojom se Krsti pripisao čitav ciklus kao njegovu pokrovitelju i naručitelju bila je pogrešnom, jer se nije prepoznala freska sv. Stjepana Prvomučenika (ostala je stoga neobnovljena), ${ }^{33}$ a koja izravno otkriva njegova stvarnog naručitelja - Krstina nećaka Stjepana III. ${ }^{34}$

${ }^{28}$ Usp. BADURINA 1979: 246. Slikovni prilog u boji tog prizora s točnom atribucijom objavljen u: RATKOVČIĆ 2014: 213.

29 JURKOVIĆ 2017.a.: 61-83.

${ }^{30}$ BADURINA 1979: 297-299.

${ }^{31}$ Usp. RATKOVČIĆ 2008: 201-202. Vidi i slikovne priloge u: JURINIĆ [2012]: 38-39; KRUHEK 2016: 170, sl. 50.

32 Usp. RATKOVČIĆ 2008: 201; JURINIĆ [2012]: 39.

${ }^{33}$ Posve se lako prepoznaje da su u svetozaru (aureoli) mlađahna sveca kameni šakavci (tamnije oker boje), potom da svetac desnom rukom drži atribut mučeništva, zelenu palminu granu koja nadvisuje rame, a da lijevom rukom u šaci istovremeno drži maketu crkve i kandilo te da je odjeven u đakonsku dalmatiku. Sve nabrojano su atributi upravo sv. Stjepana Prvomučenika; usp. BADURINA 1979: 547-548. Detaljnije u: JURKOVIĆ 2018.

${ }^{34}$ Uostalom, Stjepan je oporučno odredio mjesto svojeg ukopa u toj crkvi: »Pokop y pokoy wykowychny thela nassega Izbyramo v czrykwy Blasene Dywe Marie na Zmolcha warhu, ka ze zowe Zwetycza, Da ze onde pokopa.... (KUKULJEVIĆ SAKCINSKI 1863: 266, dok. 274). Usp. također: LOPAŠIĆ 1895: 296; LASZOWSKI 1929: 8 i 60-61; HORVAT 2010: 196; JURKOVIĆ 2018: 4 i 7. 

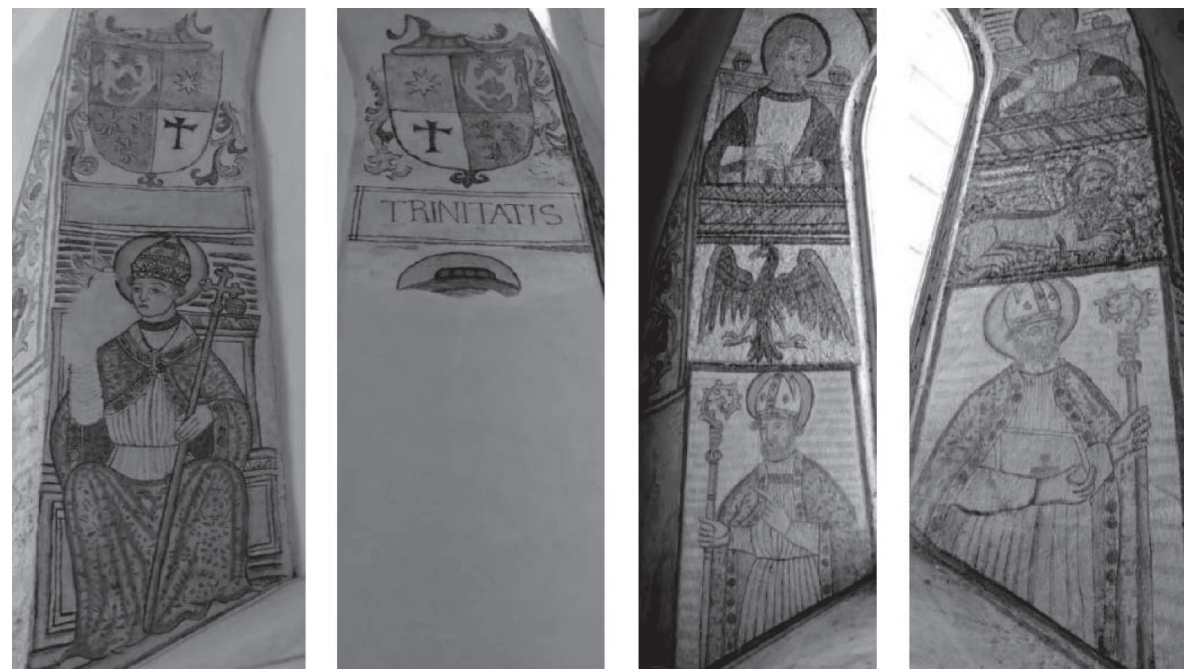

Slika 2. Prozori u svetištu crkve Rođenja B. D. Marije s crkvenim ocima:

sv. Grgurom, sv. Jeronimom, sv. Ambrozijom i sv. Augustinom (fotografije ustupio Stjepan Bezjak - Zavičajni muzej Ozalj)

Figure 2. Windows in the sanctuary of church of the Birth of Virgin Mary with Church Fathers: St. Gregory, St. Jerome, St. Ambrose and St. Augustine (photographs granted by Stjepan Bezjak - Zavičajni muzej Ozalj)

Može se, dakle, primijetiti da domaći autori, koji su imali doticaja s molitvenicima Krste i nećakinje mu Katarine Frankapan kao i s freskama u crkvi B. D. Marije u Sveticama, nisu obraćali pažnju na nazočnost lika Svetog Grgura Velikog u njima i njegovu stvarnu povezanost s Frankapanima. Bode u oči, dakle, kompozicija prozora crkve u Sveticama u kojem bi se očekivali ponad crkvenih otaca (sv. Grgura i sv. Jeronima) preostala dvojica evanđelista (sv. Luka i sv. Matej), a umjesto kojih su eto grbovi Frankapana Modruških i Ozaljskih (Slika 2). ${ }^{35}$ Bode u oči upravo odabir crkvenih otaca nad kojima su ti grbovi - sv. Grgur Veliki i sv. Jeronim! Poput strica Krste, i Stjepan III. je gledateljima »sugerirao« pokroviteljstvo i donatorstvo fresko-ciklusa u crkvama Zadobarja i Svetica narudžbom slike sv. Stjepana Prvomučenika, a s crkvenim ih je ocima sv. Grgurom Velikim i sv. Jeronimom »podsjećao« na »svoje« obiteljsko (sv. Grgur - Frankapan) $\mathrm{i} »$ naše « zavičajno (sv. Jeronim - Dalmatinac) ${ }^{36}$ podrijetlo.

${ }^{35}$ Zahvaljujem Stjepanu Bezjaku, ravnatelju Zavičajnog muzeja Ozalj, na ustupljenim fotografijama koje su poslužile u pisanju ovog rada.

${ }^{36}$ Uznosito su sv. Jeronima svećenici glagoljaši nazivali »Jerolim naš ... Dalmatin kruna hrvackoga jezika«, »Jerolim Hrvatin«, »Jerolim zašćititel i dika hrvackoga jezika«; usp. HERCIGONJA 2004: 43 


\section{DOSTOJANSTVO NE UMIRE, MIT TRAJE}

Tumačenja srednjovjekovne povijesti do 12. stoljeća bez ikonografskog razumijevanja prirode vlasti, potom bez interpretacije materijalnih simbola moći (što preko rukopisa slikovnim isticanjem, što preko preživjelih artefakata), kao i bez opisa i oslika rituala i ceremonijalnih (ne)formalnih radnji (kojima su se pokazivali stvarni odnosi moći u društvu), gotovo bi bila nemoguća. Tijekom druge polovice prošlog stoljeća na taj su metodološki segment proučavanja ne samo ranog već i kasnog srednjovjekovlja u historiografiji naročito upozoravali njemački povjesničari. ${ }^{37}$ Glede hrvatske historiografije i njezina odnosa prema kasnosrednjovjekovnoj materijalnoj i vizualnoj baštini, mora se konstatirati da se na sličan način ponašala kao i ostale nacionalne historiografije u svijetu. Ona je radom na sve brojnijoj i kvalitetnijoj pisanoj baštini poput, primjerice engleske historiografije, postupno (iz)gubila interes prema kasnosrednjovjekovnom grboslovlju, pečatoslovlju, stjegoslovlju te ostalim materijalnim i vizualnim prezentacijama simbola društvenog statusa i moći. ${ }^{38}$ Štoviše, u takvom se procesu otuđivanja znanstveno srodnih istraživača kod povjesničara izgubio osjećaj za vizualno, a kod stručnjaka za vizualno (povjesničara umjetnosti, heraldičara, sfragističara, veksilologa...) se izgubio osjećaj za pisano.

Na sličan su način znanstvene discipline pristupale problemu srednjovjekovne promidžbe kojoj je temelj bio mit. Naime, brojni su znanstvenici koji su se bavili pisanim izvorima, posve jasno istaknuli da je upravo mitsko podrijetlo (naj)moćnijih europskih obitelji bilo snažno i rašireno sredstvo propagande tijekom srednjeg, pa i ranog novog vijeka, unatoč tomu što su taj stav rijetko i skromno argumentirali vizualnim materijalima. ${ }^{39} \mathrm{~S}$ druge su strane vizualizaciju takve propagande obrađivali i povjesničari umjetnosti često koristeći rezultate medievista tako da se dolazilo do neispravnih zaključaka, ${ }^{40}$ a što je u našem slučaju rezultiralo time da ni u povjesnoumjetničkoj literaturi ni u literaturi izravno vezanoj za pisane izvore nije cjelovito prepoznato mjesto, ugled i dostojanstvo Frankapana Modruških i Ozaljskih u zajednici europskih/svjetskih moćnika na prijelazu kasnog srednjeg u novi vijek.

${ }^{37}$ SCHRAMM 1954-1978; KANTOROWICZ 1957; SCHRAMM 1983; ALTHOFF 1990, 1997 i 2003. Detaljniji prikaz u: KURELIĆ 2018: 105-106.

${ }^{38}$ To ne znači da nisu postojale studije (monografije, zbornici, katalozi i sl.), odnosno stručnjaci o takvoj baštini. Oni su međutim vrlo teško pronalazili put do sinteza pa je uključenost njihovih znanstvenih spoznaja u Braudelov tip »totalne historije« gotovo izostala. Usp. KEEN 2002: 2.

${ }^{39}$ RAYNOLDS 1984; SPIEGEL 1997: 83-110; GEARY 2009; BENEŠ 2011: 198. Detaljniji prikaz u: ŠPOLJARIĆ 2016: 121-126.

${ }^{40}$ Usp. primjerice: JURKOVIĆ 2017.a.: 82, bilj. 59. 
Podsjećanje, dakle, na mitsku obiteljsku vezu s obitelji sv. Grgura Velikog kao i bračna umreženost Frankapana Ozaljskih i Modruških s vladarskim obiteljima omogućila im je, ne samo vođenje dinastičke politike, već i dostojanstvo (dignitas) u krugu europske elite, a narativ te elite traje stoljećima i za nju dignitas ne umire. ${ }^{41}$ Stoga nije iznenađujuće javljanje sv. Grgura Velikog u frankapanskim molitvenicima te na fresci u ukopnoj crkvi jednog od Frankapana Modruškog i Ozaljskog u Sveticama. S obzirom na vjerojatan ukupni modruško-ozaljski promidžbeni fundus Frankapana navezan na sv. Grgura Velikog, navedeni molitvenici i freske izgledaju tek kao njegov skroman prežitak. No, i taj prežitak jasno upozorava na, ne samo onovremeni novi iskorak u razvoju predodžbe (gotovo pa utemeljene na ikonografskom argumentu konvenijencije) obitelji Frankapana Modruških i Ozaljskih, već odgovara i na pitanja percepcije moći njezinih članova te njihove simboličke komunikacije unutar europskih političkih/dvorskih i crkvenih krugova. Dostojanstvo je Frankapana Modruških i Ozaljskih bilo po svim parametrima neupitno i ostalo je trajno u Svetom Rimskom Carstvu njemačkog naroda. ${ }^{42}$

\section{IZVORI}

NJEMAČKO-RIMSKI BREVIJAR. = FRANKAPAN, K.; A. LANG; J. WYG 1518. Das deutsch-römisch Brevier. Venecija: Gregorius de Gregoriis. URL: http://digital.onb. ac.at/OnbViewer/viewer.faces?doc=ABO_\%2BZ221484602 ; URL: http://reader.digitale-sammlungen.de/de/fs1/object/display/bsb10860380_00001.html (23. 10. 2018.)

RAJ DUŠE. = DEŠIĆ, N. 1560. Hortulus animae: $v$ komse vzdarxuyu vre Suete gospogie po obicayuu Suete Rymske Crykque, s mnogimi deuotnimi mollituami. [Stoye Rechi Ray Dusse]. Patauio: Gratiosus Perchacinus. URL: http://reader.digitale-sammlungen.de/de/fs1/object/display/bsb10860380_00001.html (23. 10. 2018.)

FUGGEROVI GRBOVNICI. $=$ $\gg$ BSB-CodIcon online $\ll$. URL: http://codicon.digitale-sammlungen.de/start.html (23. 10. 2018).

\section{LITERATURA}

ALTHOFF, G. 1990. Verwandte, Freunde und Getreue: zum politischen Stellenwert der Gruppenbindungen im frühen Mittelalter. Darmstadt: Wissenschaftliche Buchgesellschaft.

${ }^{41}$ Usp. poglavlje »Dignitas non moritur« u: KANTOROWICZ 1957: 383-450.

${ }^{42}$ Baš kao i dignitas grofova Celjskih čiji se grbovi poput kakve paradigme i mementa na uzorgrofove Carstva gotovo bez iznimke javljaju u grbovnicima druge polovice 15. i u sljedećim stoljećima premda su smrću Ulrika II. (1456.) izumrli po muškoj liniji; usp. KURELIĆ 2018: 107-119. Vidi također zaključno poglavlje u: JURKOVIĆ 2017.a. 
ALTHOFF, G. 1997. Spielregeln der Politik: Kommunikation in Friede und Fehde. Darmstadt: Primus Verlag.

ALTHOFF, G. 2003. Die Macht der Rituale: Symbolik und Herrschaft im Mittelalter. Darmstadt: Primus Verlag.

BADURINA, A. (ur.). 1979. Leksikon ikonografije, liturgike i simbolike zapadnog kršćanstva. Zagreb: Sveučilišna naklada Liber - Kršćanska sadašnjost - Institut za povijest umjetnosti.

BAKER, P.; R. KAISER; M. PRIESTERJAHN; J. HELMARTH (eds.) 2016. Portraying the Prince in the Renaissance. The Humanist Depiction of Rulers in Historiographical and Biographical Texts. ser. Transformationen der Antike. vol. 44. Berlin: De Gruyter.

BENEŠ, C. 2011. Urban Legends. Civic Identity and the Classical Past in Northern Italy 1250-1350. University Park: Pennsylvania State University Press.

DEŠIĆ, N. 1560. Hortvlvs Animae [Stoye Rechi Ray Dusse]... Padova: Gratiosus Perchacinus.

DEŠIĆ, N. 1995. Raj duše. Rijeka: Franjevački samostan Trsat - Grad Rijeka.

FRANKAPAN, K.; A. LANG; J. WYG 1518. Das deutsch-römisch Brevier... Venecija: Gregorius de Gregoriis.

GAŠPAR, N.; R. PAVLIĆ. 2015. Raj Duše je marijanski molitvenik na prijelazu srednjega vijeka u novi vijek. F. E. Hoško (ur.). Nastanak zapadnohrvatske franjevačke pokrajine Bosne-Hrvatske prije 500 godina. Rijeka: Franjevački samostan na Trsatu - Naklada Kvarner, 145-156.

GEARY, P. 2009. Women at the Beginning. Origin Myths from the Amazons to the Virgin Mary. Princeton: Princeton University Press.

HERCIGONJA, E. 2004. Na temeljima hrvatske književne kulture: filološkomedievističke rasprave. Zagreb: Matica hrvatska.

HORVAT, J. 2006. Kultura Hrvata kroz 1000 godina. Knj. 1. T. Maštrović (ur.). dop. izd. iz 1939. Zagreb: Naklada Fran.

HORVAT, Z. 2010. Gotička crkva Blažene Djevice Marije na Smolčem Vrhu - kasnija crkva pavlinskog samostana Svetice. Vjesnik Arheološkog muzeja u Zagrebu 43/1: 193-204.

HOŠKO, E. 2007. Na vrhu Trsatskih stuba. II. proš. i dop. izdanje. Rijeka: Adamić.

HOŠKO, F. E. 1981. Marijini naslovi u molitveniku Raj duše Nikole Dešića. A. Rebić (ur.). Advocata Croatiae. Zbornik radova hrvatske sekcije VIII. međunarodnog mariološkog i XV. marijanskog kongresa. Zaragoza 3-12. 10. 1979. Teološki radovi 12. Zagreb: Kršćanska sadašnjost, 99-106.

HOŠKO, F. E. (ur.). 2015. Nastanak zapadnohrvatske franjevačke pokrajine Bosne-Hrvatske prije 500 godina. Rijeka: Franjevački samostan na Trsatu - Naklada Kvarner.

JURINIĆ, P. [2012]. Pavlinski samostan i crkva Rođenja Blažene Djevice Marije nekad i danas. Svetice: vlast. naklada.

JURKOVIĆ, I. 2017.a. O grbovima u molitvenicima koje su dali tiskati 1518. u Veneciji Krsto Frankapan sa suprugom Apolonijom Lang i 1560. u Padovi Katarina Frankapan, supruga Nikole Zrinskog Sigetskog. Zbornik Odsjeka za povijesne znanosti Zavoda za povijesne i društvene znanosti HAZU 35: 61-84. 
JURKOVIĆ, I. 2017.b. Njemačko-rimski brevijar 1518. (500. obljetnica), Istarska danica. god. 2018. Pazin: »Josip Turčinović« d.o.o., 72-75.

JURKOVIĆ, I. 2018. Vizualni identitet Stjepana III. Frankapana Ozaljskog u crkvi »Blasene Dywe Marie na Zmolcha warhu«. Croatica Christiana periodica 42/82: 1-10.

KANTOROWICZ, E. 1957. The King's Two Bodies. A Study in Mediaeval Political Theology. Princeton - New Jersey: Princeton University Press.

KEEN, M. 2002. Introduction. M. Keen; P. Cross (eds.). Heraldry, Pageantry and Social Display in Medieval England. Woodbridge - Rochester: The Boydell Press, 1-16.

KEEN, M.; P. CROSS (eds.) 2002. Heraldry, Pageantry and Social Display in Medieval England. Woodbridge - Rochester: The Boydell Press.

KLAIĆ, Vj. 1973. Povijest Hrvata: od najstarijih vremena do svršetka XIX. st. Knj. 4. Zagreb: Nakladni zavod Matice hrvatske.

KRUHEK, M. 2009. Bernardin Frankopan krčki, senjski i modruški knez - posljednji modruški Europejac hrvatskoga srednjovjekovlja, 1453.-1529. Modruški zbornik 3: 187-235.

KRUHEK, M. 2016. Knezovi modruški Bernardin i Krsto Frankopan: mačem i govorom za Hrvatsku, Modruški zbornik. Posebna izdanja. Knj. 3. Modruš: Čakavski sabor Modruše.

KUDIŠ, N. (ur.). 2012. Czriquenicza 1412: život i umjetnost Vinodola u doba pavlina. Crikvenica: Muzej Grada Crikvenice.

KUKULJEVIĆ SAKCINSKI, I. (prir.). 1863. Acta Croatica - Listine hrvatske. Zagreb: Narodna tiskarnica dra. Ljudevita Gaja.

KUNČIĆ, M. 2008. Od pošasti sačuvaj nas. Utjecaj osmanske opasnosti i kužnih epidemija na ikonografiju zavjetnih slika. Primjer Splita i Trogira u XV. i XVI. stoljeću. Zagreb: Srednja Europa.

KURELIĆ, R. 2018. Grb Ulrika II. Celjskog u Grbovniku Henrika van Heessela - jedinstven prikaz potpunoga grba u historiografiji grofova Celjskih, Zgodovinski časopis 72/1-2 (157): 105-124.

LASZOWSKI, E. 1929. Grad Ozalj i njegova okolina: mjestopisne i povjesne crtice. Zagreb: Braća Hrvatskog zmaja.

LOPAŠIĆ, R. 1895. Oko Kupe i Korane: mjestopisne i povjestne crtice. Zagreb: Naklada Matice hrvatske.

LUCERNA, C. 1925. Das Frankopani - Brevier. Der Morgen: Jugoslawische Presse für Volkswirtschaft, Kultur und öffentliches Leben 3/687: 12.

LJUBIĆ, Š. 1880. Natpis Krsta Frankopana i njegove žene Apolonije, u Mletcih, Viestnik Hrvatskoga arkeologičkoga družtva II/1: 61-62.

MESIĆ, M. 1870. Krsto Frankapan u tudjini. Rad Jugoslavenske akademije znanosti $i$ umjetnosti 13: 17-79.

MOGUŠ, M.; J. VONČINA. 1995. O molitveniku Raj Duše Nikole Dešića. M. Moguš; J. Vončina; F. E. Hoško. Raj Duše s motrišta našega vremena. Kao zasebna studija faksimilnog pretiska: N. Dešić. Raj duše. Rijeka: Franjevački samostan Trsat - Grad Rijeka. 
MOGUŠ, M.; J. VONČINA; F. E. HOŠKO 1995. Raj Duše s motrišta našega vremena. Kao zasebna studija faksimilnog pretiska: N. Dešić. Raj duše. Rijeka: Franjevački samostan Trsat - Grad Rijeka.

MOSEL, I. F. von 1835. Geschichte der Kaiserl. Königl. Hofbibliothek zu Wien. Beč: Fr. Beck'sche Universitäts-Buchhandlung.

NAGLER, G. K. 1879. Die Monogrammisten und diejenigen bekannten und unbekannten Künstler aller Schulen... Bd. V (Sl. - Z). München: Georg Franz.

PANTELIĆ, M. 1981. Senjski Lobkowiczov glagoljski kodeks iz 1359. - prototip srednjovjekovnih »liber horarum « za laike, Senjski zbornik 8/1: 355-368.

PANZERS, G. W. 1788. Annalen der ailteren deutschen Literatur, oder, Anzeige und Beschreibung derjenigen Bücher welche von Erfindung der Buchdruckerkunst. Nürnberg: Grattenauer.

RATKOVČIĆ, R. 2008. Zidne slike domaćeg majstora u Zadobarju, Volavju i Sveticama, Starohrvatska prosvjeta 35, ser. III: 195-209.

RATKOVČIĆ, R. 2014. Srednjovjekovno zidno slikarstvo u kontinentalnoj Hrvatskoj. Zagreb: Umjetnička organizacija Kultura umjetnosti.

RATKOVČIĆ, R.; V. MIKŠIĆ. 2017. Majstor od Zadobarja: srednjovjekovno slikarstvo u kapelici sv. Antuna Pustinjaka u Zadobarju, Karlovac. Katalog izložbe (Karlovac: Stari grad Dubovac, 20. IV. - 15. IX. 2017.). Karlovac: Gradski muzej Karlovac Dijecezanski muzej Zagrebačke nadbiskupije.

RAYNOLDS, S. 1984. Medieval »origines gentium« and the Community of the Realm. History 68: 375-390.

REBIĆ, A. (ur.). 1981. Advocata Croatiae. Zbornik radova hrvatske sekcije VIII. međunarodnog mariološkog $i$ XV. marijanskog kongresa. Zaragoza 3.-12. 10. 1979. Teološki radovi 12. Zagreb: Kršćanska sadašnjost.

RELJAC, V. 2015. Dešićev Raj Duše - prvo tiskano latiničko djelo hrvatske pučke teologije. F. E. Hoško (ur.). Nastanak zapadnohrvatske franjevačke pokrajine Bosne-Hrvatske prije 500 godina. Rijeka: Franjevački samostan na Trsatu - Naklada Kvarner.

SANDER, M. 1941. Le livre à figures italien depuis 1467 jusqu'à 1530 : essai de sa bibliographie et de son histoire. Vol. 4. New York: G. E. Stechert.

SCHRAMM, P. E. 1954-1978. Herrschaftszeichen und Staatssymbolik: Beiträge zu ihrer Geschichte vom dritten bis zum sechzehnten Jahrhundert. Vol. 1-3. Ser. Monumenta Germaniae historica - Schriften 13. Stuttgart: A. Hiersemann.

SCHRAMM, P. E. 1983. Die deutschen Kaiser und Könige in Bildern ihrer Zeit, 7511190. Ur. F. Mütherich. München: Prester.

SPIEGEL, G. 1997. The Past as Text. The Theory and Practice of Medieval Historiography. Baltimore: Johns Hopkins University Press.

STRČIĆ, P. 1998. Frankapan, Krsto I. Brinjski. Hrvatski biografski leksikon. sv. 4. Zagreb: Leksikografski zavod Miroslav Krleža, 414.

ŠERCER, M. 2011. Žene Frankopanke, Modruški zbornik 4 i 5: 21-81.

ŠPOLJARIĆ, L. 2016. Illyrian Trojans in a Turkish Storm: Croatian Renaissance Lords and the Politics of Dynastic Origin Myths. P. Baker; R. Kaiser; M. Priesterjahn; J. 
Helmarth (eds.). Portraying the Prince in the Renaissance. The Humanist Depiction of Rulers in Historiographical and Biographical Texts. ser. Transformationen der Antike. vol. 44. Berlin: De Gruyter, 121-156.

ŠTEFANIĆ, V. (ur.). 1969. Glagoljski rukopisi Jugoslavenske akademije. Uvod. Biblija. Apokrifi i legende. Liturgijski tekstovi. Egzorcizmi i zapisi. Molitvenici. Teologija. Crkveni govori (homiletika). Pjesme. vol. 1. Zagreb: Jugoslavenska akademija znanosti i umjetnosti.

ŠUNDALIĆ, Z. 2003. Studenac nebeski. Molitvenici u hrvatskoj književnosti od 16. do kraja 18. stoljeća (s posebnim osvrtom na Antuna Kanižlića). Split: Književni krug.

THODE, H. 1895. Der Ring des Frangipani: ein Erlebniss. Frankfurt am Main: Verlag von Heinrich Keller.

THODE, H. 1900. Frangipani's Ring. An Event in the Life of Henry Thode. London: John Macqueen.

THODE, H. 1904. Frangipani's Ring. An Event in the Life of Henry Thode. London: John Macqueen.

THODE, H. 1944. Frankopanov prsten: doživljaj, prev. Ivo Horvat. Zagreb: Hrvatsko izdavalačko bibliografsko društvo.

THODE, H. 1992. Frankopanov prsten: doživljaj, prev. Ivo Horvat. Biblioteka pretisaka. knj. 1. Rijeka: Matica hrvatska.

TULIĆ, D. 2012. Relikvijar svetog Mansueta mučenika. N. Kudiš (ur.). Czriquenicza 1412: život i umjetnost Vinodola u doba pavlina. Crikvenica: Muzej Grada Crikvenice, 173-174.

VARGA, D. 2016. Hrana, kuhinja i blagovanje u doba Zrinskih. Zagreb: Meridijani.

ZAZZERA D'ARAGONIA, F. 1617. Della famiglia Frangipani tratta della seconda parte della nobiltà dell'Italia. Napulj: Appresso Costantino Vitale.

ŽIC, N. 1933. Brevir Krsta Frankopana, Obzor 74/224: 2-3.

\section{Summary}

\section{Ivan Jurković}

\section{GREGORY THE GREAT IN THE GERMAN-ROMAN BREVIARY (1518), ON FRESCOES IN SVETICE (1541), AND IN THE HORTULUS ANIMAE (1560) COMMISSIONED BY THE FRANKAPANI OF MODRUŠ AND OZALJ}

In late mediaeval and early modern times, not a soul in Western Christendom questioned the legend that Pope Gregory the Great (590-604) descended from the Frankapani (It. Frangipani, Hung. Frangepáni). The Frankapani of Modruš and Ozalj stressed this legend as a key facet of their identity when presenting themselves to Europe's secular and ecclesiastical elites, which they were part of. For instance, the seventeenth century saw the publication of a book on the Frankapani, a book which endorsed ideas propounded by such ecclesiastical authorities as Pope Martin V (1417-31) and Pius II (1458-64), who claimed that the Counts of Krk were 
descended from the Frankapani, a noble family whose most notable scions were Pope Felix III (483-92) and his great-grandson, Gregory the Great.

Their descendance from the family of a Church Father (Gregory the Great) and regional ties to the land of another, upon which he bestowed the Glagolitic script (St. Jerome), were key elements in the Frankapans' identity-fashioning strategies over the course of the fifteenth and sixteenth centuries. This identity can be observed in visual sources, both in those printed by the Frankapani themselves, as well as those produced by (various) dignitaries familiar with the tradition. However, since such heritage survives but in traces in the Frankapani lands (spanning from Ozalj to Vinodol and Senj), this text will only address Christopher's breviary (1518), and his niece Catherine's prayer book (1560). The arguments put forward in support of the hypothesis also rely on newly discovered frescoes found in the Svetice church of the Birth of the Blessed Virgin Mary, dating back to ca. 1541.

The German-Roman Breviary (Das deutsch-römisch Brevier) was first printed by Christopher Frankapan and his wife Apollonia Lang of Wellenburg during his incarceration in Venice (1514-19). The couple edited the volume in collaboration with Jacob Wyg, a German monk. Although this year marks the Breviary's 500 ${ }^{\text {th }}$ anniversary, and notwithstanding the fact that it was referenced numerous times over the past five centuries, every generation of historians has experienced trouble finding it, and all thanks to its title. Namely, earlier manuals, as well as encyclopaedias, register it as the Petbuch die Syben Zeit von Latein in Deutsch gemacht. It was Matija Mesić who in 1870 first pointed to the existence of Christopher's breviary. Wider audiences came to know of it at the turn of the century, following the publication of Der Ring des Frangipani, a work of historical fiction penned by the German art historian Henry Thode. The success of the novel prompted a series of scientific and newspaper articles on the Breviary. Those articles, however, only went so far as to describe the Breviary. Hence, the Breviary, as well as its depictions of Gregory the Great, is yet to be subjected to critical analysis.

The Breviary contains a number of prints - a calendar adorned with allegorical representations of the months of the year, the coats of arms of the Frankapani and Langs, a series of medallions, each embellished with innumerable initials, and, finally, minuscule woodcut depictions of various symbolical figures. However, what stands out for its extraordinary beauty is a set of ten large prints, the first and last of which are identical and depict »the Coronation of the Virgin «, with Christopher and Apollonia on their knees, praying opposite one another. The remaining eight prints portray the most significant events of the New Testament, e.g. from the »Annunciation « to the »Meeting at the Golden Gate«. Each of these prints is framed by a set of medallions, occurring periodically in different combinations. Gregory the Great, one of the four Church Fathers, is to be found on two such medallions. It is probably during Christopher's Venetian thraldom that the couple »picked « the visuals of the Breviary. This selection process resulted in Gregory's frequent depictions, »at the expense « of the four evangelists (who, in terms of iconography, ought to be juxtaposed to the Church Fathers).

Another Church Father merits mentioning in this context - St. Jerome. At the time of the German-Roman Breviary's publication, Jerome was still being worshiped as the patron of the Illyrian provinces and inventor of the Glagolitic script in Croatian lands. The following can be inferred from the sequential order of saints in the medallion: Gregory is placed first, Jerome second, and only then are they followed by Ambrose and Augustine. Only two evangelists make an appearance - namely Luke and Matthew, who can be found in the upper medallion. The Old Testament Great Prophets are located in the right medallion, and the Minor ones in the lower medallion. What is to be observed between the lower medallion and the central print, that of the »Resurrection «, is a medallion depicting a Christ approached by St. Christopher from his right-hand side, and St. Apollonia from his left-hand one (Figure 1). 
What this means is that Christopher felt the need to emphasise his personal identity to the German religious masses, and he did so in an unassuming manner, namely through visual representation. In having Christ portrayed alongside St. Christopher and St. Apollonia, he »suggested « his patronage of the German-Roman Breviary, whereas in depicting the Church Fathers, he hinted at his familial (Gregory - a member of the Frankapani family) and regional (Jerome - a Dalmatian saint) legacy/ties.

Up until recently it was believed that the book kept at the Franciscan monastery in Trsat was the only remaining copy of Catherine's prayer book, Hortulus Animae (Raj duše), which once belonged to the confraternity of the Blessed Virgin Mary. It is precisely for this reason that a facsimile, accompanied by an introduction and edited by Milan Moguš and Josip Vončina, was published (1995). In describing the Hortulus Animae, Moguš and Vončina stressed the prayers addressed to St. Augustine, for they rightly observed that in those prayers Catherine beseeched health. They therefore concluded that Catherine was, at the time, »fatally ill« and »awaiting the fast-approaching hour of her death «.

The language of the prayer book is Croatian, but what sets it apart from other such writings is the fact that it was printed in the Latin script (whereas its predecessors were printed in the Glagolitic script). The prayer book does not contain any illustrations depicting Gregory the Great or St. Catherine. However, the feast days of the two saints are recorded in bold, red letters in the calendar located at the beginning of the book. Furthermore, the book contains a prayer offered to St. Catherine. It is important to mention the fact that the Hortulus Animae contains two prayers composed by Gregory the Great. Those prayers can be found preceding the last chapter, which contains the »Holy Masses of the Blessed Virgin Mary « in Latin. The title of the prayers is located in the header of the page, written in simple, red letters: »Mollitua S. Gargura «, which translates to »The Prayer of St. Gregory«. The Hortulus Animae ends in St. Gregory's prayers, and in Croatian at that, which signals the wish of its editors, Catherine Frankapan and Nicholas Dešić, to »situate « it in an appropriate and memorable place within the book. And why not? Was Catherine not descended from the same family as Gregory the Great?

The restoration of the church of the Birth of the Blessed Virgin Mary in Svetice (southwest of Ozalj), conducted by the Conservation Department in Karlovac (1992-2005), unearthed frescoes dating back to ca. 1541. Among them is a fresco depicting Gregory the Great, located beneath one of no fewer than three Gothic Frankapan coats of arms. It was those coats that attracted the specialists' attention, whereas the saint's figure was nothing but rightly attributed, allowing the restoration of the painting. The chapter on Gregory was thus laconically concluded. Besides, the conservators' primary aim was to ascertain whether the frescoes were painted by the same (local) artistic workshop which furnished the village churches on the Frankapani estate of Ozalj.

Gregory the Great is to be observed in the lower left window strip of the eastern wall of the Svetice church. He is depicted sitting on a throne, embellished/along with his iconographic attributes; a staff ending in a cross in his left hand, a tiara on his head, and a white dove next to his right ear. In the strip above him one can observe a quartered Frankapani coat of arms. The only thing visible in the lower right window strip is a fragment of the cardinals' red mitre, the attribute of St. Jerome, and above him the slogan »Trinitatis«, topped off by a mirrored Frankapani coat of arms (Figure 2).

The frame of the neighbouring window, in the centre of the church, is, however, subdivided into three strips. The central strip contains a zoomorphic symbol on either side of the window; an eagle and St. John above it on the left, and a winged lion and St. Mark above it on the right. Beneath the zoomorphic symbols the remaining two Church Fathers, St. Ambrose (on the left) and St. Augustine (on the right), can be found. Those parts of the fresco cycle have been rightly attributed, explained, and restored. One can therefore effortlessly recognise that the 
iconographic system found in the church is identical to the one in Christopher's breviary - four Church Fathers and two evangelists... Like his uncle Christopher, Stephen III »suggested « his patronage of the fresco cycle in the Svetice church by commissioning a depiction of St. Stephen the Martyr, as well as »hinting « at »his « familial (Gregory - a member of the Frankapani family) and »our « regional (Jerome - a Dalmatian saint) origin.

Their insistence on their purported ties to Gregory the Great's family, as well as their marital network, by which they were linked to many of Europe's ruling families, enabled the Frankapani of Ozalj and Modruš not just to implement dynastic policies, but also gave them dignity (dignitas) among Europe's elites. The narrative of these elites had a long-standing tradition, and dignitas was still very much alive within it. It is therefore no surprise that Gregory the Great should appear in the Frankapani breviaries and in the church a member of the family was buried in. Those breviaries and frescoes represent the following: firstly, a new, contemporary shift in how this Croatian aristocratic family was conceptualised; secondly, how the power of the family's members was perceived; thirdly, their symbolic communicative value within the context of European political/courtly and ecclesiastical higher circles. The dignitas of the Frankapani of Modruš and Ozalj was, by all parameters, unquestioned and enduring within the Holy Roman Empire.

Keywords: Gregory the Great, the Frankapani of Modruš and Ozalj, the German-Roman Breviary, frescoes in Svetice, the prayer book Hortulus Animae, symbolic communication, (self)promotion, sixteenth century

Ivan Jurković

Juraj Dobrila University of Pula

Pula (Croatia)

ivanj@unipu.hr 